Goldschmidt 2021 Abstract

https://doi.org/10.7185/gold2021.5037

\section{Tracing weathering and anthropogenic controls of groundwater geochemical cycling from tropical watershed}

\author{
MR. SARATH PULLYOTTUM KAVIL, MSC ${ }^{1}$, DAMIEN \\ CARDINAL $^{1}$, RAMANANDA CHAKRABARTI ${ }^{2}$, JEAN \\ RIOTTE $^{3}$, VVSS SARMA ${ }^{4}$, ARNAUD DAPOIGNY ${ }^{5}$, \\ VÉRONIQUE VAURY ${ }^{1}$, LAURENT RUIZ ${ }^{2,3}$, BENJAMIN \\ BAUD $^{2}$ AND B.S.K. KUMAR ${ }^{4}$
}

${ }^{1}$ Sorbonne Université

${ }^{2}$ Indian Institute of Science, Bangalore

${ }^{3}$ GET-OMP, IRD, Toulouse

${ }^{4}$ NIO-CSIR, Visakhapatnam

${ }^{5}$ LSCE/IPSL, CEA-CNRS-UVSQ

Presenting Author: sarath.pullyottum-kavil@locean.ipsl.fr

Intense exploitation of groundwater resources associated with increasing agricultural activity along with extensive utilization of the fertilizers can lead to significant alterations in the hydrological and biogeochemical cycles in shallow aquifers. In the current study we use geochemical and isotopic tracers to understand the origin and mixing of groundwater in aquifers and chemical weathering under contrasting land use: the intensely cultivated Berambadi and the pristine forested Mule Hole catchments. The Berambadi region experiences tropical semiarid climatic conditions, with depleting water table and salinization of groundwater while Mule Hole is situated inside Bandipur National Park, thus ideal to understand the hydrogeochemical cycles in undisturbed conditions. Both Mule Hole and Berambadi aquifer recharge occurs through surface water percolation and to a lesser extent from lateral flow. Groundwater samples were collected during the summer (dry) season in March and South-West monsoon (wet) season in August 2019 from both watersheds.

Silicon isotope fractionation in natural waters is majorly controlled by soil-water interaction leading to dissolution of primary minerals and formation of secondary minerals and also from biogenic sources and uptake. The $\delta^{30} \mathrm{Si}$ of groundwater samples from Berambadi and Mule Hole (average value of 1.05 $0.51 \%$ ) were heavier than gneissic bedrock composition $(-0.34 \pm$ $0.08 \%$ ) and global groundwater average value $(0.67 \pm 0.8 \%)$. Shallow groundwater samples $(<10 \mathrm{~m}$ depth) showed large variability in $\delta^{30} \mathrm{Si}$ values $\left(0.39 \%{ }^{-3.4 \%}\right)$ and $\mathrm{Ge} / \mathrm{Si}$ ratio $(0.25$ $3.38)$ compared to deeper aquifers $(0.39 \% 0-1.15 \%$ and $0.25-0.87)$ as a result of saprolite heterogeneity and biotic influences. The $\delta^{30} \mathrm{Si}$ values show strong inverse correlation with DSi and $\ln (\mathrm{DSi})$ only in Berambadi fitting a Rayleigh fractionation model with fractionation factor of -0.91 . Additionally, $\delta^{30} \mathrm{Si}$ positively correlates with $\mathrm{Ge} / \mathrm{Si}$ on Berambadi indicating preferential removal of Si fraction depleted in heavy isotopes and Ge that can be attributed to plant uptake. On the other hand Mule Hole shows weak correlation between $\delta^{30} \mathrm{Si}$ and $\mathrm{Ge} / \mathrm{Si}$ indicating active biotic recycling. The ${ }^{87} \mathrm{Sr} /{ }^{86} \mathrm{Sr}$ in groundwater samples from Berambadi (0.71122-0.7257) shows wider range compared to Mule Hole
(0.71660-0.72001), possibly arising from the contribution of anthropogenic inputs related to agriculture. Results indicates considerable contribution of anthropogenic influence in the hydrogeochemistry of groundwater from cultivated watershed. 